\title{
The Manifestation Of Familiness Resources And Psychological Capital As Familiness Capital: A Conceptual Analysis
}

\author{
René van Wyk, University of Johannesburg, South Africa
}

\begin{abstract}
The non-financial foundation of family business performance is largely under-researched. More clarity is needed to identify the theoretic origin and outcomes of the familiness concept. This conceptual analysis explores the non-financial competitive advantage of familiness functioning optimally as familiness capital (FamCap). The notion of familiness is explored in terms of psychological capital (PsyCap) with FamCap as outcome variable. Family businesses seem to nurture familiness resources in the form of the PsyCap constructs of self-efficacy, hope, optimism and resilience. These resources could advance the optimal functioning of FamCap. The presence of FamCap should sustain a positive competitive advantage in a family firm.
\end{abstract}

Keywords: Familiness Capital (FamCap); Psychological Capital; Founder Legacy; Financial Returns; Wealth Creation

\section{INTRODUCTION}

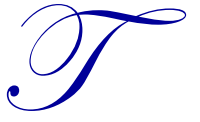

he important role that family business plays in global economic growth is well recognised. Family businesses seem to be the backbone of economies worldwide by possessing a driving force that generates superior returns. Family firms, in general, show higher financial returns and market dominance (Bughin and Colot, 2010). Over 70\% of businesses in the United States are family-owned (Reynolds, 2012) with female entrepreneurs playing an increasingly significant role (Bledsoe and Oatsvall, 2010). In Sweden, family businesses contribute $20 \%$ of the gross domestic product and $25 \%$ of total employment (Bjuggren, Johansson and Sjögren, 2011). The Small Enterprise Development Agency (SEDA) indicates that family businesses contribute $50 \%$ to South Africa's economic growth (Odgers Berndtson, 2013). Notwithstanding the dominance of family firms globally, it is notably under-researched (Blodgett, Dumas and Zanzi, 2011). The following question needs to be answered: "What are the contributing factors that lead to the prominence and success of family businesses in global economies?"

The familiness character of family firms explains the idiosyncratic dynamics that contribute to the performance of family firms (Habbershon, Williams and Macmillan, 2003; Pearson, Carr and Shaw, 2008). Familiness operates as an ecosystem in the generation of idiosyncratic resource bundles and skills in forming agency advantages (Habbershon, 2006). Familiness is the result of the family's interaction with the firm's social and behavioural resources that leads to long-term financial returns (Tokarczyk, Hansen, Green and Down, 2007). Familiness may lead to outcomes beyond financial returns (Pearson, Car and Shaw, 2008).

While the scrutiny of the familiness construct is important, it is equally important to examine its relationship with accompanying theories (Pearson et al., 2008). Although the financial performance of family businesses has been largely explained, an attempt should be made to uncover the details of the non-financial performance of family firms and to provide a supporting theory (Zellweger and Nason, 2008). Thus far, the noneconomic and emotional aspects that underlie the positive organizational outcomes of family firms remain underresearched (Debicki, Matherne, Kellermanns and Chrisman, 2009). This conceptual analysis inspects PsyCap as a possible explanation of the non-financial emotional contribution of family-firm performance. 
Similar to the explanation of familiness as contributing to family-firm performance, PsyCap is deemed to be leading to positive organizational outcomes. PsyCap has been recognised as a core construct in constructive organizational functioning, such as employee well-being (Luthans, Youssef, Sweetman and Harms, 2013) and work performance (Avey, Reichard, Luthans and Mhatre, 2011; Peterson, Luthans, Avolio, Walumbwa and Zhang, 2012). As PsyCap is regarded as an alignment of the flow between personal and organizational goals (Luthans et al., 2004), similarly FamCap is seen as the optimal flow of familiness in family firms (Van Wyk, 2012). FamCap is seen as the functioning of familiness in an optimal flow and alignment between the family, the firm, and its resources. Familiness functions on a continuum between constrictive ineffective organizational energy and distinctive organizational energy (Habbershon and Williams, 1999; Van Wyk, 2012). Only when familiness is functioning optimally and constructively in a positive flow does it function as FamCap with sustained organizational energy. This is represented in Figure 1 (Van Wyk, 2012). As far as could be ascertained, the prevalence of PsyCap and its relationship with familiness and FamCap have not been investigated.

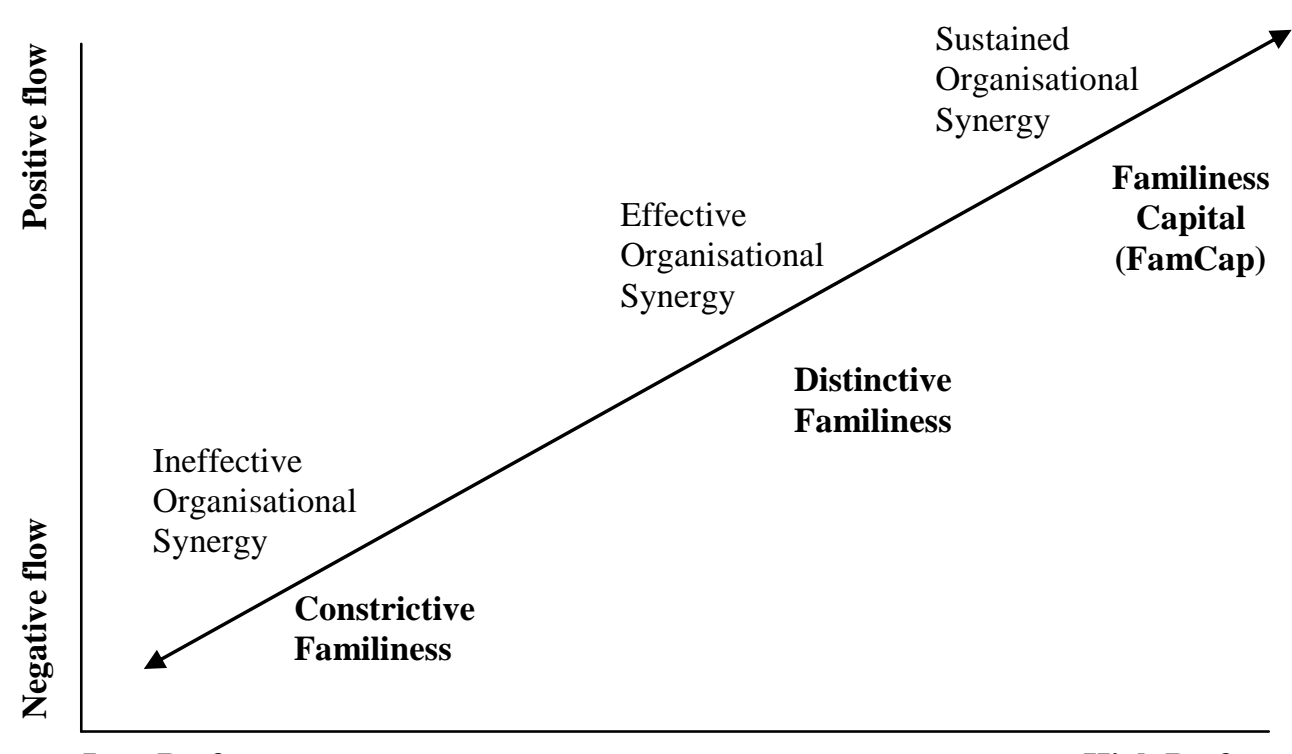

Low Performance

High Performance

Figure 1: The Continuum of Constrictive Familiness versus Distinctive Familiness Source: (Van Wyk, 2012)

The author's research questions are: 1) "Is there a relationship between familiness and PsyCap?" and 2) "Does the reciprocal relationship between familiness and PsyCap contribute to the optimal flow of FamCap?" This paper is a philosophical argument for the hypothetical reciprocal relationship between familiness and PsyCap in advancing FamCap.

\section{PURPOSE OF THE STUDY}

This conceptual analysis is a first attempt at exploring the non-financial performance of familiness and its possible relationship with PsyCap. An investigation is undertaken of the familiness of family firms as introduced by Habbershon and Williams (1999), Habbershon, Williams, and Macmillan (2001), and Habbershon et al. (2003), using the theoretical lens of positive psychological PsyCap (Luthans, 2007; Luthans, Luthans and Luthans, 2004; Luthans, Youssef, and Avolio, 2007). As far as could be ascertained, this relationship has not been argued before. 


\section{THEORETICAL BACKGROUND}

\section{Definition of Familiness}

Familiness is defined as the sum of the resources of a family firm consisting of capital factors of human, social, and financial nature (Danes, Stafford, Haynes, and Amarapurkar, 2009). This discussion explores the phenomena of non-financial human and social factors in family firms. Reportedly, familiness plays an important role in the financial and perceived achievement of family firms (Danes et al., 2009). Familiness does not always function at an optimal level. The functioning of familiness is regarded as operating on a continuum between constrictive and distinctive performance (Habbershon et al., 2003). Only when familiness functions optimally does it do so as familiness capital - FamCap (Van Wyk, 2012). FamCap is the dynamic processes that take place in the optimal flow of familiness by way of the family firm resources. The constrictive functioning of familiness is not denied. The coexistence of the family, the governance of the firm (Hirigoyen, 2009) and family harmony (Venter, Van der Merwe, and Farrington, 2012) often pose threats to the survival and performance of the firm. Similarly, positive psychology should not be oversimplified and its complexity should not be denied (Cilliers and May, 2010). As positive psychology enhances personal well-being (Guse, 2010), it is argued that familiness and PsyCap could similarly enhance FamCap. The current discussion focusses on familiness characteristics in family firms that support PsyCap. It is argued that this interaction leads to a competitive advantage when familiness functions optimally as flow in the form of FamCap.

\section{PROBLEM STATEMENT AND RESEARCH OBJECTIVES}

As far as could be ascertained, the concept of familiness functioning as Familiness Capital (FamCap) and its relationship with PsyCap characteristics have not been explored before. The importance of the familiness character of family businesses deems it necessary to investigate its different forms and influence on economic activity (Steier, 2009), as well as its antecedents and outcomes (Pearson et al., 2008). The positive psychological component in the familiness character of family businesses and its optimal functioning as FamCap seem to be associated with psychological capital - PsyCap (Van Wyk, 2012) - which consists of the constructs of efficacy, optimism, hope, and resilience (Luthans et al., 2004; Luthans and Youssef, 2004). This discussion contributes to the family firm literature in three ways. Firstly, it is an investigation into the relationship of familiness against the theoretic background of PsyCap. Secondly, the alignment of PsyCap and familiness supplies an explanation for the manifestation of FamCap in family businesses. Thirdly, a model is proposed that explains the relationship between familiness resources that support PsyCap factors which could lead to FamCap.

\section{RESEARCH DESIGN}

\section{Research Approach}

In this conceptual analysis, the author investigates the familiness characteristics that support the PsyCap concepts of self-efficacy, hope, optimism and resilience. This is an attempt to present a new perspective of FamCap, as supported through the reciprocal relationship between familiness and PsyCap factors. This conceptual analysis is an unsystematic approach to present a proposed philosophical relationship (Green, Johnson, and Adams, 2006). It is an attempt to group the familiness characteristics as seemingly related to the PsyCap constructs of self-efficacy, hope, optimism, and resilience. The literature sources that were targeted were both in the PsyCap and familiness domains. No other literature could be found on FamCap as it is a new construct, only recently dubbed (Van Wyk, 2012). Data were analysed by discussing the different familiness factors as they conceptually seem to support the PsyCap concepts. The different familiness factors were sorted and discussed under the PsyCap concepts of selfefficacy, hope, optimism, and resilience.

\section{Theoretical Relationship between FamCap and PsyCap}

The concept of positive organizational behaviour and PsyCap originates from post-modern positive psychology, as introduced by Seligman (1999). The positive psychological movement developed by Martin Seligman (1999) challenges traditional psychology by focusing on people's strengths - on what is being done right, 
rather than on looking for weaknesses, pathology, and dysfunctional behaviour. The movement's core construct PsyCap - as applied in business, is founded in psychological resource theories (Avey, Luthans, Smith, and Palmer, 2010). The PsyCap resources provide a theoretical explanation of the positive mechanisms and capacities that result in people's well-being. According to these theories, psychological resources are defined as entities that are valued as either inherently essential in their own right (i.e., self-esteem and inner peace) or a method of obtaining essential valued outcomes; for instance, capital and social support (Hobfoll, 2002). The criteria for positive organizational behaviour have been identified as 1) being based on measurable theory; 2) receptive to development being open (state-like) and not static (trait-like); and 3) being performance-oriented (Luthans 2002a, 2002b; Luthans et al., 2007; Luthans and Youssef, 2007).

The combination of the positive organizational behavioural characteristics was termed psychological capital and popularised by the acronym PsyCap (Luthans et al., 2007). PsyCap is seen as the driving force of human capital (Luthans et al., 2007). The four elements of PsyCap applied to human capital in business are explained as follows (Avey, Luthans, Smith, and Palmer, 2010; Luthans et al., 2007):

- $\quad$ Self-efficacy - confidence to engage in the required effort to successfully accomplish difficult tasks and successfully activate skills and talents to execute tasks.

- Hope - perseverance in successfully reaching goals, energising pathways and goals in motivational behaviour.

- Optimism - optimistic positive attribution of succeeding in the present and future and adopting an orientation of positive explanatory styles when facing adversity.

- $\quad$ Resilience - an ability to robustly bounce back beyond difficulties and hardship to reach success. Resilience is a means of recovering and restoring when faced with failure or misfortune.

The PsyCap factors of hope, confidence, resilience, and optimism have implications for the overall wellbeing of employees and building of sustainable organizations (Luthans et al., 2013). Positive emotions and resources create positive workplace experiences and work engagement (Ouweneel, Le Blanc, and Schaufeli, 2012). PsyCap is manageable at relatively low monetary cost, in contrast to financial capital and tangible assets (Luthans et al., 2004). A study by Luthans, Avey, and Patera (2008) indicates that PsyCap web-based training contributed to the development of PsyCap in a broad cross-section of employees. PsyCap is regarded as a critical resource in coping with occupational stress, which the World Health Organization regards as a global epidemic in today's organizations (Avey, Luthans, and Jensen, 2009). It may thus also be useful to family firms and may well already be present in their functioning.

\section{The Relationship between PsyCap and Positive Organizational Behaviour}

The relationship between PsyCap and positive organizational behaviour outcomes in business has been reported in various studies. Positive states are related constructive work outcomes in the following studies:

- The self-perception of authentic leadership of entrepreneurs, PsyCap explaining $22 \%$ of the variance in the prediction of authentic leadership (Jensen and Luthans, 2006)

- Job satisfaction and organizational commitment (Avey et al., 2011; Larson and Luthans, 2006)

- $\quad$ Work performance (Avey et al., 2011; Peterson et al., 2012)

- $\quad$ Performance and satisfaction (Luthans, Avolio, Avey, and Norman, 2007)

- $\quad$ Work performance of Chinese employees (Luthans, Avey, Clapp-Smith, and Li, 2008a)

- $\quad$ Psychological well-being over time (Avey, Luthans, Smith, and Palmer, 2010)

- $\quad$ Organizational citizenship behaviours (Avey, Luthans, and Youssef, 2010; Avey, Wernsing, and Luthans, 2008)

- Innovative behaviour of employees in the fashion industry in India (Jafri, 2012)

- $\quad$ Creative performance (Sweetman, Luthans, Avey, and Luthans, 2012)

- Individuals with healthy PsyCap are attractive potential employees as they tend to be productive and have healthy work attitudes (Cole, Daly, and Mak, 2009)

- $\quad$ PsyCap helps people to be re-employed when they become unemployed (Cole, Daly, and Mak, 2009) 
- $\quad$ Short training interventions of PsyCap have improved individuals' PsyCap and on-the-job performance (Luthans, Avey, Avolio, and Peterson, 2010)

PsyCap and trust played a mediating role between authentic leadership and work-group citizenship behaviour and performance in a study of 146 financial institutions (Walumbwa, Luthans, Avey and Oke, 2011).

Apart from the positive association of PsyCap with constructive organizational outcomes, it has the advantage of being negatively related to unconstructive work outcomes, such as the following:

- $\quad$ Involuntary and voluntary absenteeism (Avey, Patera, and West, 2006)

- $\quad$ Intentions to quit (Avey et al., 2009; Avey et al., 2010)

- $\quad$ Stress symptoms, job-search behaviours (Avey et al., 2009)

- $\quad$ Organizational cynicism (Avey, Luthans, and Youssef, 2010; Avey, Wernsing, and Luthans, 2008)

A reciprocal relationship between familiness and PsyCap should lead to FamCap resulting in financial returns and wealth creation. This suggested relationship is illustrated in Figure 2.

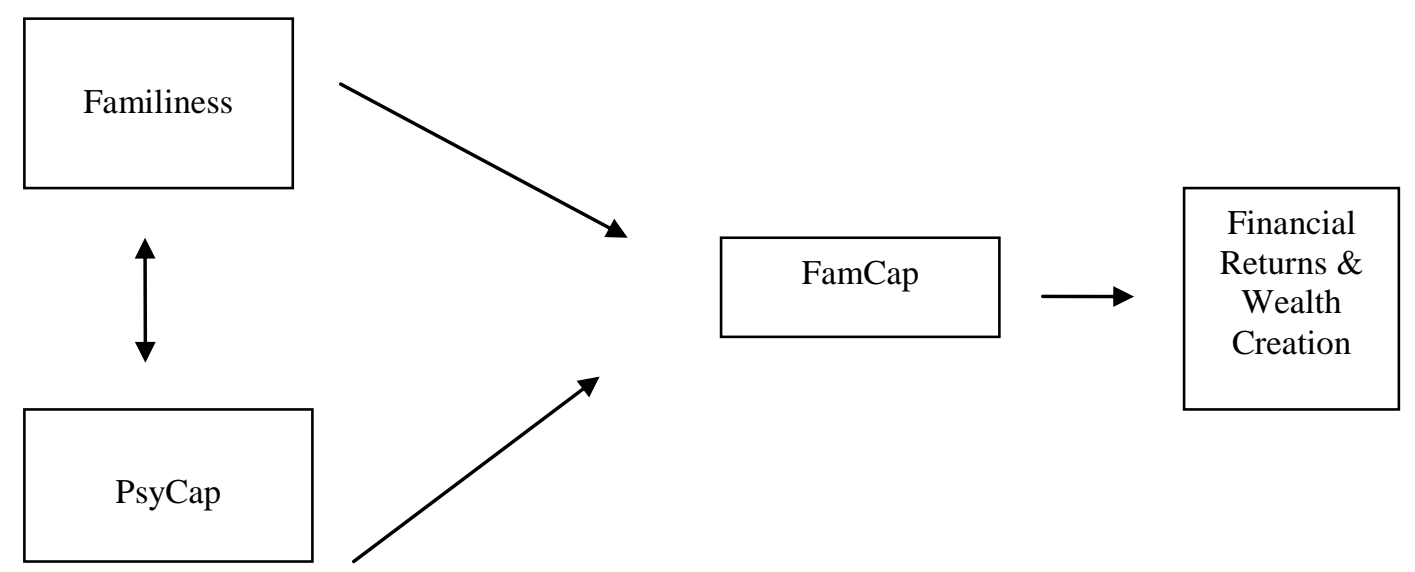

Figure 2: Suggested Association between Familiness and PsyCap with FamCap Leading to Superior Financial Returns and Wealth Creation

In the discussion that follows, the PsyCap concepts of self-efficacy, hope, optimism, and resilience are explained supported by certain familiness phenomena in family businesses.

\section{SELF-EFFICACY}

Self-efficacy, as coined by Bandura (1993, 1997), refers to a self-belief in being capable of producing actions in order to accomplish goals (Maddux, 2005; O'Brien, 2003). Self-efficacy is defined as the individual's conviction that his or her abilities activate the resources of motivation and cognition that lead to the necessary action to successfully and appropriately accomplish tasks in specific circumstances (Stajkovic and Luthans, 1998). Selfefficacy develops as a person's confidence grows through previous learning experiences that involve mastering goals by way of positive social support, feedback, and physiological and psychological arousal (Luthans and Youssef, 2004). A meta-analysis of 114 studies showed a significant positive correlation between self-efficacy and work-related performance (Maddux, 2005). It is argued that self-beliefs develop over time through different encounters which encourage exploring and internalising diverse behaviours. Self-efficacy is significantly related to taking charge in work situations (Onyishi and Ogbodo, 2011). In family firms, self-efficacy seems to be present in many forms as discussed accordingly. 


\section{Founder Legacy}

Self-efficacy seems to be further embedded in the founder legacy formed in family businesses. Imprinting theory underscores the lasting effect of the vision, culture, and operational policies established by the founder on the consecutive generations (Schein, 1983). The founder legacy that often accompanies the functioning of a family business also serves, over many generations, as a guideline for the enterprise and is of great assistance when acquiring businesses (Venter, 2007). This phenomenon is referred to as 'founder legacy centrality', where succeeding generations make strategic decisions on the basis of the vision of the founder and the culture set by him or her (Kelly, Athanassiou and Critteden, 2000). For this reason, it is emphasised that the founder-legacy should be built into and carried forward to family-business acquisitions (Steen and Welch, 2006). By carrying forward this legacy, the personal commitment of the family, and its sincerity toward the acquisition, are instilled (Steen and Welch, 2006).

\section{Distinctive Identity}

Family businesses seem to have a personality or identity that leverages performance (Hubler, 2009; Zellweger, Eddleston, and Kellermanns, 2010). Through the formation of an identity, the perpetuation of strong family values, ethics, and morals take place manifesting as the soul in family firms (Hubler, 2009). This identity of family firms is inspired by a common vision that is directed by the daily nurturing of the spiritual principles, conscience, and values of the family. These are leveraged as a business advantage that leads to success. The social identity and agency theories explain how family business owners identify with the reputation of their firms and care about it (Block, 2010). It also explains the negative relationship between family firm ownership and reputationdamaging actions, such as downsizing, which explains the avoidance of large job cuts. Identity confirmation that is embedded in the culture of the family firm (Milton, 2008) creates a competitive advantage by portraying a firm pride that is supported by a long-term vision (Zellweger, Kellermanns, Eddleston, and Memili, 2012).

This distinctive identity that is formed in a family business seems to be supported by mental models (Kellermanns and Barnett, 2008). Family firms that accommodate mental models that are neither too similar nor too dissimilar should improve their self-efficacy. Mental models that are too dissimilar prevent cohesiveness and strategic action, while mental models that are too similar could lead to group thinking.

\section{Advanced Results}

Self-efficacy can present itself in family businesses through a culture that accomplishes advanced results by means of high-performance work systems (Tsao, Chen, Lin, and Hyde, 2009). Furthermore, non-family employees' identification with the family firm is significantly and positively related with both profitability and the continuity or survival of family firms (Vallejo, 2009a).

\section{Leadership}

It may plausibly be argued that the leadership of family firms' owners to a common purpose, which is supported by identity confirmation, should help to create a culture of self-efficacy in a family firm. Employees are inclined to be more committed to the goals of a family firm when they observe the intense commitment of the family leadership (Zahra, Hayton, Neubaum, Dibrell, and Craig, 2008), especially where identity confirmation takes place (Klein, 2008). This commitment and identity confirmation are advanced by way of a family firm culture of transformational leadership, where the charisma of the leader and an appealing vision result in the identification of the followers with the leader (Eddleston, 2008). The bridging of the gap between the family and the business is usually guided by one family member who acts as 'institutional champion' in promoting the norms and values of the family firm (Parada, Nordqvist, and Gimeno, 2010).

\section{HOPE}

Hope is defined as the positive state of motivation, derived from a sense of success through agency energised goal orientation - and pathways - preparation to accomplish those goals - (Snyder, 2000). Hope consists of 
both affective and cognitive characteristics (Lopez, Snyder and Pedrotti, 2003). People engage cognitively in hopeful behaviour by seeking and using pathways and forming agentic behavioural patterns to reach particular goals (Lopez et al., 2003; Snyder, Rand and Sigmon, 2005). Simultaneously, emotional feedback is monitored during goal-directed behaviour (Lopez et al., 2003). Goal-setting is initiated by developing proposals of schemes through mental rehearsals and showing confidence and preparedness through contingency planning and continuous regoaling (Luthans and Youssef, 2004). Often more than one pathway is sought through self-reference to continue with goal-directed behaviour to progress on problem-solving pathways (Snyder et al., 2005). It is by means of way power (pathways) that business leaders gain hopeful behaviours by creating or exploring different optional pathways to overcome obstacles (Luthans, Van Wyk and Walumbwa, 2004). Such leaders do not experience obstacles as threats, but rather see them as opportunities to address problems through different methods of accomplishing goals. It is proposed that the FamCap construct in family businesses is related to the tendency of family business leaders to develop way power by exploring different alternative pathways in turbulent environments, creating an orientation of hopeful expectation.

\section{Social Involvement}

Family businesses form strong community ties and are socially responsive in taking action to support their communities (Zellweger et al., 2012). The family and the firm join forces in forming a family firm's social capital (Arregle, Hitt, Sirmon and Very, 2007). Family businesses seem to become easily involved in the philanthropic care and appreciation of their communities (Ward, 2004). The social responsibility activities of family businesses are generally under-reported (Lester and Canella, 2006). It seems that the true social responsiveness of family businesses to the needs in their social communities is not clear and may be rather under-estimated (Venter, 2008). Under-reporting of philanthropy can be ascribed to the family's tendency towards privacy to avoid media exposure (Poutziouris, Steier and Smyrnios, 2004). Notwithstanding these arguments, a report of Fortune 500 companies shows that family-owned businesses are more involved in social responsibility issues than businesses that are not family owned (Stavrou, Kassinis and Filotheou, 2007). In a study of 221 family businesses, the social support that family firms provided to their communities accounted for almost $43 \%$ of the variation in the social responsibility of family businesses to the community (Niehm, Swinney and Miller, 2008).

\section{Entrepreneurial Development of Others}

In addition to supporting the under-privileged, family businesses also empower individuals to become independent functioning entrepreneurs. For example, De Beers is actively involved in the creation and successful establishment of small- and medium-sized businesses for the historically disadvantaged (Luiz, 2002). Under the umbrella of Altron, Xerox South Africa has instituted franchising opportunities for historically disadvantaged people (Luiz, 2002). Pick n Pay has over a 1000 franchise stores (Pick n Pay, 2002).

\section{Customer Service}

Family firms place a high emphasis and priority on service to the customer (Danes, Loy and Stafford, 2008; Prichard, 2004, 2005; Venter, 2007). The sensitivity to customer-centred values leads to profitability and growth (Craig, Dibbrell and Davis, 2008). The study of 572 small-family businesses in the USA by Danes et al., (2008) indicates that $44.6 \%$ of these firms saw a positive reputation with their customers as the most important business goal. Customer care translates into loyalty to the family firm with positive outcomes, such as purchasing behaviours (Okoroafo and Koh, 2009). Though Gärnter et al. (2012) report no difference between the customer-orientation policies of family and non-family enterprises, this study does not explain the difference in customer satisfaction.

\section{Moral Values}

Family firms are regarded as having exceptional ethical values compared to non-family firms (Blodgett, Dumas and Zanzi, 2011). A comparison of mission statements of family and non-family firms in the United States indicated that family businesses showed a higher frequency of ethical values - guidance to integrity and honest conduct, environmentalism and social responsibility (Blodgett, Dumas, and Zanzi, 2011). A significant positive link seems to exist between collaborative dialogue in family businesses and moral infrastructure (Sorenson, Goodpaster, 
Hedberg, and $\mathrm{Yu}, 2009)$. A positive significant path analysis was reported between collaborative dialogue and ethical norms, as well as between ethical norms and family social capital which, in turn, led to solid firm performance according to a study of 212 family firms in the USA (Sorenson et al., 2009). On the one hand, family ownership that is too strongly concentrated on family members tends to open up the possibility of less ethical conduct and thus constrictive familiness (O'Boyle, Rutherford and Pollack, 2010). On the other hand, highly ethical behaviour over several generations, with shared values and that is aimed at retaining the family business, can make a family business more ethically focused. This may result in intangible capital that enhances the firm's performance.

\section{OPTIMISM}

Seligman (1999) explains optimism as the propensity of an individual to attribute failure and adversity only to temporary causes which are specific to the situation, and could not be prevented, rather than to permanent internal traits. Optimism is also seen as a tendency to anticipate that positive things will transpire in the future (Carver and Scheier, 2003, 2005). Individuals with an optimistic outlook thus tend to regard problems as momentary, external to themselves and as event specific (Reivich and Gillham, 2003; Seligman, 2005). This is opposed to pessimists who interpret problems as permanent, intrinsic attributions.

Optimism is nurtured by balancing a flexible compassionate view of past events, appreciating present circumstances and striving toward prospects in the future (Luthans and Youssef, 2004). This tendency of having positive expectations influences an individual's attitude toward expectations and indirectly directs the constructive anticipation of future events (Carver and Scheier, 2005). In this way, learned helplessness is counteracted by forming a positive explanatory style of events (Peterson and Steen, 2005). Through optimism, goal-directed behaviour is formed that involves a pursuit of desirable goals and a confident expectancy that these goals are attainable.

\section{Trust}

A competitive and strategic advantage of trust seems to exist in family firms (Sundaramurthy, 2008). The two factors that are regarded as contributing most to family business success are the trust between family members, their healthy relationship with employees (Flottum, 2011; Sawyers, 2010) and their passion for their business (Reynolds, 2012). Too much trust in family firms could reduce controls that prevent fraud detection (Bledsoe and Wessels, 2006). Family values are often maintained by sustaining the success of a family firm (Parada et al., 2010). Trust could be advanced by the following:

- Long-term relationships that family businesses form with customers, employees and suppliers (Royer, Simons, Boyd and Rafferty, 2008; Sundaramurthy, 2008)

- $\quad$ Tendency of family firms to remain loyal to their employees in times of market lows (Stavrou et al., 2007)

- $\quad$ Avoidance of downsizing (Block, 2010)

- $\quad$ Employment growth during prosperous times (Kellermanns, Eddleston, Barnett and Pearson, 2008)

However, trust is only enhanced when family members and employees perceive treatment as fair and harmonious (Van der Merwe, Venter and Farrington, 2012). Family businesses have a general altruistic tendency to resist the temptation to downsize during market lows (Cater and Schwab, 2008:45; Lee, 2006). Under such conditions, these firms often prefer to show altruism by keeping staff employed, to use other forms of cost-cutting and to maintain a long-term goal orientation (Cater and Schwab, 2008; Lee, 2006). There seems to be a special bond that supports non-economic links between family owners and employees, leading to organizational commitment (Vallejo and Langa, 2010).

\section{Innovation}

Schein (1983) regards innovation as one of the essential characteristics of family-business founders (Schein, 1983). Family firms tend to induce a long-term vision that generates innovation, maximises profit (Bughin and Colot, 2010) and generates new product development (Cassia, De Massis and Pizzurno, 2012). Family businesses seem to concentrate on a shared vision that embraces the family and the business which, in turn, seems to 
lead to advanced business performance, limited conflict (Hughes, 2007) and strategic innovation (Bughin and Colot, 2010). The general long-term vision of family firms improves innovation through internationalisation (Claver, Rienda and Quer, 2009) and new product development (Cassia et al., 2012). A study of 179 family firms indicated that a long-term orientation and family-to-firm unity through participative governance-advanced corporate entrepreneurship in such firms (Eddleston, Kellermanns and Zellweger, 2012). Family influence by way of entrepreneurial culture had a significant relationship with the entrepreneurial orientation of family firms in a study of family firms in Malaysia (Zainol, Daud and Muhammad, 2012). Family-business ownership has a positive influence on gaining shareholder valuation when mergers and acquisitions are announced (Feito-Ruiz and Menéndez-Requejo, 2010), which could be an indication of an optimistic view of family firms. However, a negative effect on mergers and acquisitions has been experienced in the event of major shareholder ownership.

\section{Generation Succession}

Successful inter-generational handovers could further advance the competitive advantage of family firms (Royer et al., 2008) and the absorption of the family owner's interest at death (Goldberg, 2007). This possibly serves in promoting an optimistic family business culture. The strategic relevance of a family member as successor is based on the lifelong and general knowledge of the family business gained by the family member who has a history of relationships with clients, suppliers, employees and competitors (Royer et al., 2008). These factors of successful inter-generational transition could contribute to a general culture of optimism in a family firm.

There also seems to be an inherent strength in family-business succession that enhances familiness due to the prevalence of long-term decision-making and the goal of generational continuity (Feito-Ruiz and MenéndezRequejo, 2010). Every generation's succession of a family business seems to add to the strength of the ties that exist between the family business, its historic achievements and its evolution in an innovative search for future prospects. It is likely that successful generation transition would strengthen the resilience of a family firm. However, stagnation is often evident in a second-generation family firm, leading to constrictive functioning. Second-generation family members are often more concerned about preserving family wealth, so they tend to be risk averse (Molly, Laveren and Deloof, 2010). It is also a matter of concern that family businesses show a low succession rate of only about one third to the following generations (De Massis, Chua and Chrisman, 2008; Poza 2007). The growth rate is often reported as decreasing after the first-generation succession. However, it is not affected by subsequent generation transitions (Molly et al., 2010). Successful family businesses seem to have a long-term orientation with transgenerational succession goals (Miller and Le Brenton-Miller, 2005).

\section{RESILIENCE}

Resilience is defined as a category of events that can be classified as methods of constructive adjustment to misfortune in the circumstances of great hardship (Masten and Reed, 2005, p. 75). Coutu (2002) identifies resilient people as those who have the ability to unwaveringly accept reality, see life as meaningful, and have an ability to adapt significantly to change. Resilience is cultivated by initiating strategies that are asset-, risk- and processfocused (Luthans and Youssef, 2004). Resilience refers to the continuous process of using skills and building competencies when facing adversity in stressful circumstances (Capuzzi and Gross, 2000; Lewis, 2000; Masten and Reed, 2005).

Through resilience, a positive sense of well-being is facilitated and enhanced. This is due to a person's positive social competence and problem-solving orientation, which is a transactional process between the individual and the environment (Bernard, 1991; 1993; 1996; 1997). Certain protective factors seem to play a role in psychosocial resilience. These are problem-solving and self-regulating abilities, pro-social behaviour and an organised environment (Masten and Reed, 2005).

At an organizational level, resilience is manifested in the processes and structures that provide the capacity to bounce back by dynamically absorbing tension and balancing synergy (Klarreich, 1998). Luthans, Vogelgesang and Lester (2006) propose proactive and reactive human resource development strategies to develop resilience. Proactive processes include increasing psychological resources, decreasing risk factors and facilitating resilience, 
whereas reactive processes include generating positive emotions, making attributions to external factors and showing endurance and self-development. Resilience in family businesses is demonstrated by the following:

- $\quad$ These businesses do not function in highly-profitable sectors only but also in less profitable sectors (Levie and Lerner, 2009).

- $\quad$ Family-business owners tend to work longer hours and earn significantly less pay than non-family business managers (Levie and Lerner, 2009).

A United States National Family Business Panel of 311 small-family firms indicated that male-owned small-family businesses that were exposed to natural disaster without federal disaster assistance showed significant resilience - this was not the case with female-owned family businesses (Danes, Lee, Amarapurkar, Stafford, Haynes and Brewton, 2009). On the other hand, resilience of small-family firms can be threatened by a lack of internal controls and too much trust in employees (Bledsoe and Wessels, 2006).

\section{Competitiveness}

Familiness is related to different forms of entrepreneurial leadership in family firms (Kansikas, Laakkonen, Sarpo and Kontinen, 2012). An overall entrepreneurial orientation of family firms has a positive influence of growth, especially in second-generation family businesses (Casillas, Moreno and Barbero, 2010). Family-business expertise seems to be strengthened by its tendency to integrate skilled knowledge to facilitate turn-around strategies during difficult times (Chirico and Salvato, 2008). Entrepreneurs integrate skills by forming network ties with professionals, family and friends as sources of advice (Robinson and Stubberud, 2011).

The competitive advantage of family firms can be explained from a resource-based perspective and the propensity of these firms to protect the supply of sources from threats of imitation continuously (Barney, 1991). Family firms are vigilant in recognising these competitive threats by using shared mental models to manage hazards (Kellermanns and Barnett, 2008). Identity confirmation allows a family firm to create a competitive advantage, making a family firm a hard-to-imitate resource (Milton, 2008). Family-business owners have an ability to convince others of their vision to create and perpetuate a new venture successfully through pure determination and perseverance (Aronoff and Baskin, 2005). Resilience can be jeopardised by the negative association between the ownership of family firms and low investment in research and development (Chen and Hsu, 2009). This can, however, be overcome by extending board membership to independent outsiders.

\section{Risk Aversion}

Family firms do not only show higher profits but, depending on the situation, are more risk averse than other companies (Bonilla, Sepulveda and Carvajal, 2010; Hiebl, 2013). This theoretically implies that the assets of a portfolio of family firms are higher than expected at a certain level of risk. However, where family firms are high in ownership and conservatism, this can be significantly negatively related to low research and development investments (Chen and Hsu, 2009), as well as poor corporate governance and restricted growth (Tsai, Kuo and Hung, 2009). These are key factors in obtaining a competitive advantage. Family firms are especially risk averse when they are in danger of losing their socio-emotional wealth (Stockmans, Lybaert, and Voordeckers, 2010). This is a non-financial condition that has to do with the affective connection of the family with the firm, such as perpetuation of the business and the exercise of control by the family. Family firms manage to attain low agency cost, through homogeneity that enhances competitiveness and firm value (Heath, 2011; Pukthuanthong, Walker and Theingtham, 2013; Swamy, 2011). Calculated risk is a key aspect in the survival and maintenance of a competitive advantage in a family firm.

\section{Strategic Flexibility}

The survival and resilience of family firms seem to be related to their ability to foster a positive culture of strategic flexibility by the family business leadership (Eddleston, 2008; Zahra et al., 2008). In its fourth generation of 100 years of family ownership, the Sames Auto Group propagates flexibility during difficult times (Sawyers, 2010). A family firm culture that values stewardship makes a significant positive contribution to strategic flexibility and the resultant superior performance (Zahra et al., 2008). Strategic flexibility is enhanced by a family firm culture 
that challenges the status quo, accommodates employees' inputs, and shows a willingness to take calculated risks (Eddleston, 2008; Zahra et al., 2008). This culture must either be willing to take risks or must be risk-averse (Stockmans et al., 2010). Therefore, inertia and inflexibility should lead to a lack of resilience in family businesses.

\section{Transformational Leadership}

Family-business leadership is further characterised by being transformational and enhancing group cohesion (Vallejo, 2009b). Transformation of family businesses is shown in an ability to abandon old methods of doing things and a willingness to transform and employ legitimate changes and turn-around strategies by means of an institution champion (Parada et al., 2010; Salvato, Chirico and Sharma, 2010). Family firms tend to develop a strong affective commitment to knowledge integration capabilities, which could strengthen their resilience (Chirico and Salvato, 2008). To be able to do this, the successful family-business management team willingly integrates newly-accessed knowledge, notwithstanding the obstacles of potential relationship conflicts (Chirico and Salvato, 2008). Successful family businesses seem to be able to generate turn-around strategies when facing crises (Cater and Schwab, 2008). The strengths of family-business turn-around strategies are embedded in the "familiness" concept. They often rely on the long-term and strong social relationships that family members have, and willingly draw on knowledge in the form of external expertise. They then coordinate these processes (Cater and Schwab, 2008).

The author proposes a FamCap model, supported by family firm familiness resources in interaction with PsyCap, as shown in Figure 3. This FamCap model identifies the various familiness resources that support the PsyCap constructs of self-efficacy, hope, optimism and resilience that could lead to FamCap.

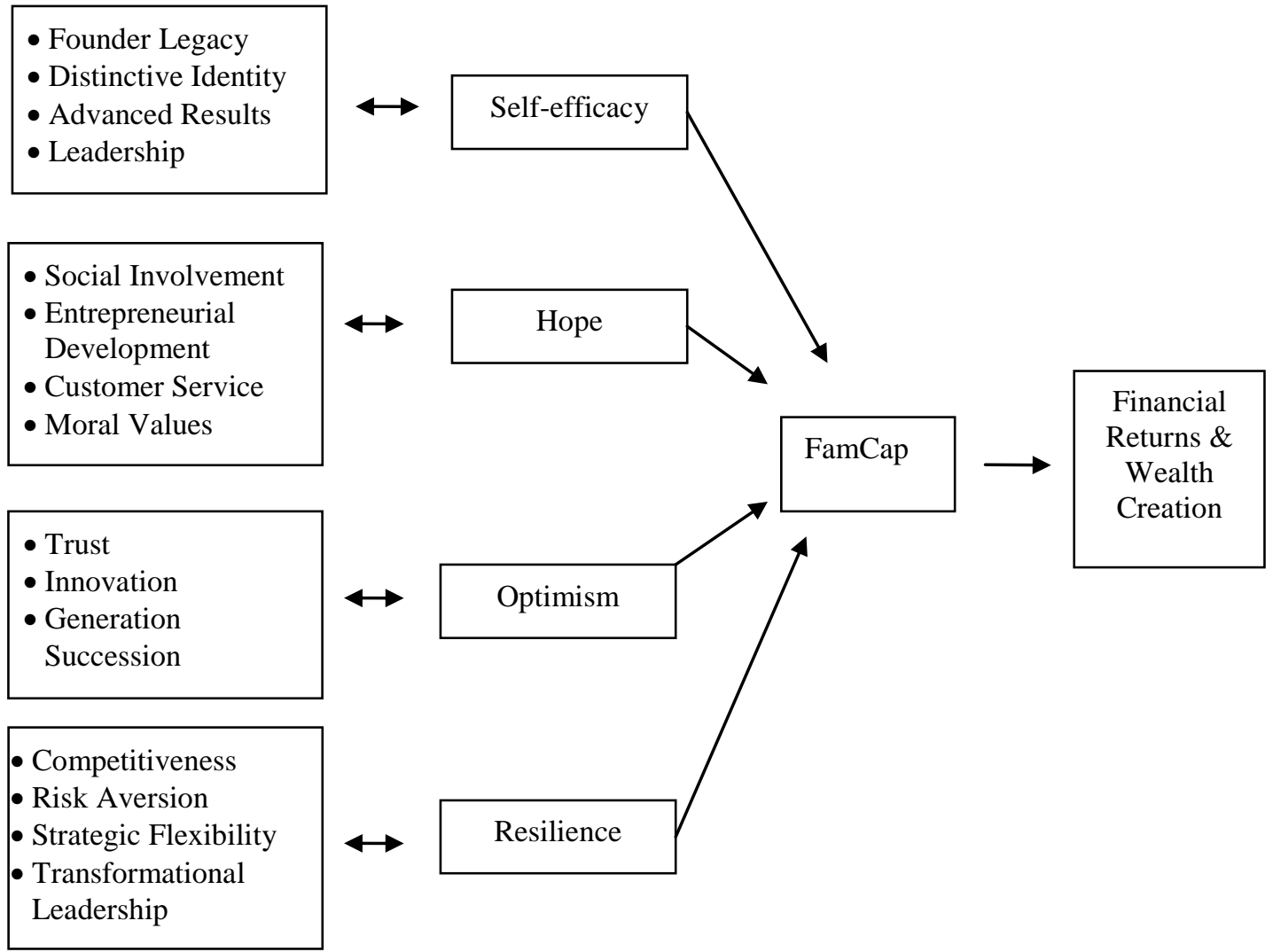

Figure 3: FamCap Model: Reciprocal Family Firm Resources and PsyCap Factors Leading to a Competitive Advantage in the Form of FamCap with Financial Returns and Wealth Creation

It is proposed that the above family resources, which are associated with the PsyCap factors of selfefficacy, hope, optimism, and resilience, are not mutually exclusive but are overlapping. It is proposed that these family firm resources could interact in the different PsyCap factors. 


\section{DISCUSSION}

This conceptual analysis attempts to provide some answers to the need expressed by Zellweger and Nason (2008b) and Debicki et al. (2009) to provide theory concerning the non-financial performance, non-economic and emotional aspects that underlie the positive organizational outcomes of family firms. This discussion indicates how the PsyCap constructs of self-efficacy, hope, optimism and resilience are supported by specific characteristics and resources in family firms. It also suggests that the relationship of PsyCap with familiness could affect the performance in family firms in the form of FamCap. This provides arguments on how cultural and organizational conditions that foster PsyCap in family businesses can also enhance FamCap. The key points in the current discussion support the prevalence of PsyCap in sustaining FamCap. However, more rigorous empirical work needs to be done to measure the relationship between PsyCap and familiness.

\section{Practical Implications}

Family businesses should be made aware of the advantages of advancing PsyCap with the potential of improving their competitive advantage, as well as of perpetuating the family business effectively. Both family and non-family businesses should encourage and practice the different facets of PsyCap and programmes should be put in place to promote self-efficacy, hope, optimism and resilience. Conversely, non-family businesses should be made aware of the possible sustained positive competitive advantages that familiness resources in relation to PsyCap involve. These characteristics can be learned and should be advanced in businesses.

\section{LIMITATIONS AND FUTURE RESEARCH}

The aim of this paper has been to explore the possible prevalence of PsyCap and its relationship with FamCap. The above discussion emphasises the importance of a PsyCap culture in family businesses. Subjectivity could have played a role in the arguments and relationships that were suggested. No empirical data are available to support the arguments of the proposed relationships depicted in Figures 1 and 2. For this reason, it is suggested that the proposed relationships be tested empirically. Further research needs to be done to objectively refine the empirical evidence of the existence of these phenomena. The familiness characteristics could be involved in more than one PsyCap construct. Empirical evidence is needed to clearly differentiate the familiness factors that predict PsyCap in the form of self-efficacy, hope, optimism and resilience.

Future discussions should include the risks involved in the absence of PsyCap and familiness in family businesses. Future research should investigate the empirical measurement of FamCap, as well as its relationship with PsyCap. Such research should address the following research questions: What are the familiness-PsyCap factors that contribute to FamCap? Do the familiness-PsyCap factors lead to low turnover and absenteeism? What is the relationship between FamCap on the one hand and other work-related factors, such as satisfaction, commitment and organizational citizenship behaviour, on the other? Is PsyCap more prevalent in family businesses than in nonfamily businesses?

\section{RECOMMENDATIONS FOR MANAGEMENT}

The familiness-PsyCap interaction should nurture FamCap. The presence of PsyCap in family businesses should be evaluated to assist management to take strategic actions. The fostering of familiness-PsyCap factors in family firms should lead to a competitive advantage. A further advantage is that it is accomplished by relative low financial output (Luthans et al., 2004). Family businesses should develop training programmes to enhance familiness-PsyCap as a competitive advantage in family firms.

\section{CONCLUSION}

Although much has been written on PsyCap, as far as could be established, the relationship between PsyCap and FamCap in family businesses has not been examined. This conceptual analysis is an indication that a positive form or organizational behaviour seems to exist in family businesses. This contributes to the intense familiness that characterises family-owned businesses and to their superior global performance. The familiness- 
PsyCap relationship in family businesses is a culture worth nurturing. This should contribute to performance. It is recommended that the culture of FamCap in family businesses, as partially explained by PsyCap in this article, may yield strategic advantages and value creation. FamCap, as partially explained by familiness-PsyCap relationship, clarifies the phenomenon of the non-financial performance of the family business to some extent. The reciprocity between familiness and PsyCap resources seems to advance FamCap, leading to financial returns and value creation.

\section{AUTHOR INFORMATION}

René van Wyk is Associate Professor in the Department of Industrial Psychology and People Management. She is an industrial psychologist registered at the South African Health Professions Council. She is the author of numerous peer-reviewed articles in organizational behaviour. She has supervised a number of master's and doctoral students and has developed course material for a doctoral programme in organizational behaviour. René's research interest is in positive organizational behaviour and family businesses. E-mail: vanwyk.rene@gmail.com

\section{REFERENCES}

1. Aronoff, G., \& Baskin, O. (2005). Effective leadership in the family business. Marietta, GA: Family Enterprises.

2. Arregle, J., Hitt, M.A., Sirmon, D.G., \& Very, P. (2007). The development of organisational social capital: Attributes of family firms. Journal of Management Studies, 44(1), 73-95.

3. Avey, J.B., Luthans, F., \& Jensen, S. (2009). Psychological capital: A positive resource for combating employee stress and turnover. Human Resource Management, 48, 677-693.

4. Avey, J.B., Luthans, F., Smith, R.M., \& Palmer, N.F. (2010). Impact of positive psychological capital on employee well-being over time. Journal of Occupational Health Psychology, 15, 17-28.

5. Avey, J.B., Luthans, F., \& Youssef, C.F. (2010). The additive value of positive psychological capital in predicting work attitudes and behaviours. Journal of Management, 36(2), 430-452.

6. Avey, J.B., Patera, J.L., \& West, B.J. (2006). The implications of positive psychological capital on employee absenteeism. Journal of Leadership and Organisational Studies, 13, 42-60.

7. Avey, J., Reichard, R., Luthans, F., \& Mhatre, K.H. (2011). Meta-Analysis of the impact of positive psychological capital on employee attitudes, behaviours, and performance. Human Resource Development Quarterly, 22(2), 127-152.

8. Avey, J., Wernsing, T.S., \& Luthans, F. (2008). Can positive employees help positive organisational change? Impact of psychological capital and emotions on relevant attitudes and behaviours. The Journal of Applied Behavioral Science, 44(1), 48-70.

9. Bandura, A. (1993). Perceived self-efficacy in cognitive development and functioning. Educational Psychologist, 28, 117-148.

10. Bandura, A. (1997). Self-efficacy: The exercise of control. New York: Freeman.

11. Barney, J.B. (1991). Firm resources and sustained competitive advantage. Journal of Management, 17, 99120.

12. Bernard, B. (1991). Fostering resilience in kids: Protective factors in the family, school, and community. Portland, OR: Northwest Regional Educational Laboratory.

13. Bernard, B. (1993). Turning the corner: From risk to resilience. Portland, OR: Northwest Regional Educational Laboratory.

14. Bernard, B. (1996). From research to practice: The foundations of the resilience paradigm. Resilience in Action, 1, 7-11.

15. Bernard, B. (1997). Changing the condition, place, and view of young people in society: An interview with young development pioneer Bill Lofquist. Resilience in Action. 2, 7-18.

16. Bjuggren, C., Johansson, D., \& Sjögren, H. (2011). A note on employment and gross domestic product in Swedish family owned business. Family Business Review, 24(4), 362-371.

17. Bledsoe, M.T., \& Wessels, S.B. 2006. Family owned business fraud: The silent thief. Journal of Business \& Economics Research, 4(1), 47-51.

18. Bledsoe, M.T., \& Oatsvall, R.J. 2010. Entrepreneurship - Women's Business. International Business \& Economics Research Journal - Special Edition, 9(13), 47-55. 
19. Block, J. (2010). Family management, family ownership, and downsizing: Evidence from S\&P 500 firms. Family Business Review, 23, 109-130.

20. Blodgett, M., Dumas, C., \& Zanzi, A. (2011). Emerging trends in global ethics: A comparative study of U.S. and international family business values. Journal of Business Ethics, 99, 29-38.

21. Bonilla, C.A., Sepulveda, J., \& Carvajal, M. (2010). Family ownership and firm performance in Chile: A note on Martinez et al.'s evidence. Family Business Review, 23, 148-152.

22. Bughin, C., \& Colot, O. (2010). Does family governance encourage innovation? Journal of Business and Economics, 2(2), 199-218.

23. Capuzzi, D., \& Gross, D.R. (2000). Approaches to prevention. In D. Capuzzi \& D. R. Gross (Eds.), Youth at risk. A prevention resource for counselors, teachers, and parents, (pp. 23-40) ( $3^{\text {rd }}$ ed.). Alexandria, VA: American Counseling Association.

24. Casillas, J., Moreno, A., \& Barbero, J. (2010). A configurational approach of the relationship between entrepreneurial orientation and growth of family firms. Family Business Review, 23(1), 27-44.

25. Cassia, L., De Massis, A., \& Pizzurno, E. (2012). Strategic innovation and new product development in family firms. International Journal of Entrepreneurial Behaviour and Research, 18(2), 198-232.

26. Cater, J., \& Schwab, A. (2008). Turnaround strategies in established small family firms. Family Business Review, 21, 31-50.

27. Carver, C.S., \& Scheier, M. (2003). Optimism. In S. J. Lopez \& C. R. Snyder (Eds.), Positive Psychological Assessment (pp. 75-90). Washington, DC: American Psychological Association.

28. Carver, C.W., \& Scheier, M.F. (2005). Optimism. In S. J. Lopez \& C. R. Snyder (Eds.), Positive Psychological Assessment (pp. 231-243). Cape Town: Oxford University Press.

29. Chen, H., \& Hsu, W. (2009). Family ownership, board independence, and R\&D investment. Family Business Review, 22, 347-362.

30. Chirico, F., \& Salvato, C. (2008). Knowledge integration and dynamic organisational adaptation in family firms. Family Business Review, 21, 169-181.

31. Cilliers, F., \& May, M. (2010). The popularisation of positive psychology as a defence against behavioural complexity in research and organisations. SA Journal of Industrial Psychology, 36(2). doi:

10.4102/sajip.v36i2.917

32. Claver, E., Rienda, L., \& Quer, D. (2009). Family firms' international commitment: The influence of family-related factors. Family Business Review, 22, 125-135.

33. Cole, K., Daly, A., \& Mak, A. (2009). Good for the soul: The relationship between work, wellbeing and psychological capital. Journal of Socio-Economics, 38, 464-474.

34. Coutu, D.L. (2002). How resilience works. Harvard Business Review, 80, 46-55.

35. Craig, J., Dibbrell, C., \& Davis, P. S. (2008). Leveraging family-based brand identity to enhance firm competitiveness and performance in family businesses. Journal of Small Business Management, 46(3), 351-371.

36. Danes, S.M., Loy, J.T., \& Stafford, K. (2008). Business planning practices of family-owned firms within a quality framework. Journal of Small Business Management, 46, 395-421.

37. Danes, S.M., Lee, J., Amarapurkar, S., Stafford, K., Haynes, G., \& Brewton, K.E. (2009). Determinants of family business resilience after a natural disaster by gender of business owner. Journal of Developmental Entrepreneurship, 14(4), 333-354.

38. Danes, S.M., Stafford, K., Haynes, G., \& Amarapurkar, S.S. (2009). Family capital of family firms. Family Business Review, 22, 199-215.

39. Debicki, B.J., Matherene, C.F., Kellermanns, F.W., \& Chrisman, J.J. (2009). Family business research in the new millennium. Family Business Review, 22, 151-166.

40. De Massis, A., Chua, J.H., \& Chrisman, J.J. (2008). Factors preventing intra-family succession. Family Business Review, 21(2), 183-199.

41. Dyer, W.G., \& Dyer, W.J. (2009). Putting the family into family business research. Family Business Review, 22, 216-219.

42. Eddleston, K.A. (2008). Commentary: The prequel to family firm culture and stewardship: The leadership perspective of the founder. Entrepreneurship Theory and Practice, 32, 1055-1060.

43. Eddleston, K.A., Kellermanns, F.W., \& Zellweger, T.M. (2012). Exploring the entrepreneurial behavior of Family Firms: Does the stewardship perspective explain differences? 36(2), 347-367. 
44. Feito-Ruiz, I., \& Menéndez-Requejo, S. (2010). Family firm mergers and acquisitions in different legal environments. Family Business Review, 23, 60-75.

45. Flottum, K. (2011). A day in Wisconsin. Bee Culture, 139(9), 60-63.

46. Gäartner, B., Feldbauer-Durstmüller, B. \& Duller, C. 2012. Stakeholder goals in family businesses: Evidence from upper Austria. International Business \& Economics Research Journal, 11(11), 1203-1210.

47. Goldberg, M. (2007). Choice of entity for the family business. Journal of Applied Business Research, 23, 7-20.

48. Green, B., Johnson, C.D., \& Adams, A. (2006). Writing narrative literature reviews for peer-reviewed journals: Secrets of the trade. Journal of Chiropractic Medicine, 5(3), 101-117.

49. Guse, T. (2010). Positive psychology and the training of psychologists: Students' perspectives. SA Journal of Industrial Psychology, 36(2). doi: 0.4102/sajip.v36i2.848.

50. Habbershon, T.G. (2006). Commentary: A framework for managing the familiness and agency advantages in family firms. Entrepreneurship Theory and Practice, 30, 879-886.

51. Habbershon, T.G., \& Williams, M.A. (1999). Resource based framework for assessing the strategic advantages of family firms. Enterprising Families Initiative, Working Paper \#101. Philadelphia PA: University of Pennsylvania.

52. Habbershon, T.G., Williams, M., \& Macmillan, I. (2001). A unified systems theory of family firm performance. Enterprising Families Initiative, Working Paper \#103. Philadelphia PA: University of Pennsylvania.

53. Habbershon, T.G., Williams, M., \& Macmillan, I.C. (2003). A unified systems perspective of family firm performance. Journal of Business Venturing, 18, 451-465.

54. Heath, J. (2011). Business ethics and the 'end of history' in corporate law. Journal of Business Ethics, 102(1), 5-20.

55. Hiebl, M.R.W. (2013). Risk aversion in family firms: What do we really know? The Journal of Risk Finance, 14(1), 49-70.

56. Hirigoyen, G. (2009). Conciliating finance and management into family firms. Revue Française de Gestion, 198, 393-411.

57. Hobfoll, S.E. (2002). Social and psychological resources and adaptation. Review of General Psychology, 6, 307-324.

58. Hubler, T.M. (2009). The soul of family business. Family Business Review, 22, 254-258.

59. Hughes, C. (2007). Resolving conflict in the family business. LP/GAS, 14.

60. Jafri, H. (2012). Psychological capital and innovative behaviour: An empirical study on apparel fashion industry. The Journal Contemporary Management Research, 6(1), 42-52.

61. Jensen, S.M., \& Luthans, F. 2006. Relationship between entrepreneurs' psychological capital and their authentic leadership. Journal of Managerial Issues, 18, 254-273.

62. Kansikas, J., Laakkonen, A., Sarpo, V., \& Kontinen, T. (2012). Entrepreneurial leadership and familiness as resources for strategic entrepreneurship. International Journal of Entrepreneurial Behaviour, 18(2), 141158.

63. Kellermanns, F.W., \& Barnett, T. (2008). Commentary: What were they thinking? The role of family firm mental models on threat recognition. Entrepreneurship Theory and Practice, 23, 999-1006.

64. Kellermanns, F.W., Eddleston, K.A., Barnett, T., \& Pearson, A. (2008). An exploratory study of family member characteristics and involvement: Effects on entrepreneurial behaviour in the family firm. Family Business Review, 21, 1-14.

65. Kelly, L.M., Athanassiou, N., \& Critteden, W.F. (2000). Founder centrality and strategic behaviour in the family-owned firm. Entrepreneurship Theory and Practice, 25, 27-42.

66. Klarreich, S. (1998). Resilience: The skills needed to move forward in a changing environment. In S. Klarreich (Ed.), Handbook of Organisational Health Psychology: Programs to make the workplace healthier, (pp. 219-238). Madison, CT: Psychosocial Press.

67. Klein, S.B. (2008). Commentary and extension: Moderating the outcome of identity confirmation in family firms. Entrepreneurship Theory and Practice, 32, 1083-1088.

68. Larson, M., \& Luthans, F. (2006). Potential added value of psychological capital in predicting work attitudes. Journal of Leadership and Organisational Studies, 13, 75-92.

69. Lee, J. (2006). Family firm performance: Further evidence. Family Business Review, 19, $103-114$. 
70. Lester, R.H., \& Canella, A.A. (2006). Interorganisational familiness: How family firms use interlocking directorates to build community-level social capital. Entrepreneurship Theory and Practice, 30, 755-775.

71. Levie, J., \& Lerner, M. (2009). Resource mobilization and performance in family and nonfamily businesses in the United Kingdom. Family Business Review, 22, 23-38.

72. Lewis, R.E. (2000). Resilience: Pathway to protective factors and possibilities for self-righting narratives. In D. Capuzzi \& D.R. Gross (Eds.), Youth at risk. A prevention resource for counselors, teachers, and parents, (pp. 41-78) ( $3^{\text {rd }}$ ed.). Alexandria, VA: American Counselling Association.

73. Lopez, S.J., Snyder, C.R., \& Pedrotti, J.T. (2003). Hope: Many definitions, many measures. In S. J. Lopez \& C. R. Snyder (Eds.), Positive psychological assessment, (pp. 91-108). Washington, DC: American Psychological Association.

74. Luiz, J. (2002). Small business development, entrepreneurship and expanding the business sector in a developing economy: The case of South Africa. Journal of Applied Business Research, 18, 53-68.

75. Luthans, F. (2002a). Positive organisational behaviour: Developing and managing psychological strengths. Academy of Management Executive, 16, 57-72.

76. Luthans, F. (2002b). The need for and meaning of positive organisational behaviour. Journal of Organisational Behavior, 23, 695-706.

77. Luthans, F. (2007). Hope, optimism, and other business assets. Gallup Management Journal. Retrieved April 4, 2007, from http://www.gmj.gallup.com/ content/25708 /hope-optimism-and-other-businessassets.aspx

78. Luthans, F., Avey, J.B., Avolio, B.J., \& Peterson, S.J. (2010). The development and resulting performance impact of positive psychological capital. Human Resource Development Quarterly, 21, 41-67.

79. Luthans, F., Avey, J.B., Clapp-Smith, R., \& Li, W. (2008). More evidence on the value of Chinese workers' psychological capital: A potentially unlimited competitive resource? International Journal of Human Resource Management, 19, 818-827.

80. Luthans, F., Avey, J.B., \& Patera, J.L. (2008). Experimental analysis of a web-based training intervention to develop positive psychological capital. Academy of Management Learning \& Education, 7, $209-221$.

81. Luthans, F., Avolio, B., Avey, J., \& Norman, S. (2007). Positive psychological capital: Measurement and relationship with performance and satisfaction. Personnel Psychology, 60, 541-572.

82. Luthans, F., Luthans, K., \& Luthans, B. (2004). Positive psychological capital: Going beyond human and social capital. Business Horizons, 47, 45-50.

83. Luthans, F., Van Wyk, R., \& Walumbwa, F.O. (2004). Recognition and development of hope for South African organisational leaders. Leadership \& Organization Development Journal, 25, 512-527.

84. Luthans, F., Vogelgesang, G.R., \& Lester, P.B. (2006). Developing the psychological capital of resilience . Human Resource Development Review, 5, 25-44.

85. Luthans, F., \& Youssef, C.M. (2004). Human, social, and now positive psychological capital management: Investing in people for competitive advantage. Organisational Dynamics, 33, 143-160.

86. Luthans, F., \& Youssef, C. M. (2007). Emerging positive organisational behavior. Journal of Management, 33, 321-349.

87. Luthans, F., Youssef, C.M., \& Avolio, B.J. (2007). Psychological capital: Developing the human competitive edge. Oxford: Oxford University Press.

88. Luthans, F., Youssef, C.M., Sweetman, D.S., \& Harms, P.D. (2013). Meeting the leadership challenge of employee well-being through relationship PsyCap and health PsyCap. Journal of Leadership \& Organisational Studies, 20(1), 118-133.

89. Maddux, J.E. (2005). Self-Efficacy. In C. R. Snyder \& S. J. Lopez (Eds.), Handbook of positive psychology, (pp. 277-298). Cape Town: Oxford University Press.

90. Masten, A.S., \& Reed, M.J. (2005). Resilience in development. In C. R. Snyder \& S. J. Lopez (Eds.), Handbook of positive psychology (pp. 74-88). Cape Town: Oxford University Press.

91. Miller, D., \& Le Brenton-Miller, I. (2005). Managing for the long run: Lessons in competitive advantage from great family businesses. Boston, MA: Harvard Business School Press.

92. Milton, L.P. (2008). Unleashing the relationship power of family firms: Identity confirmation as a catalyst for performance. Entrepreneurship Theory and Practice, 32, 1063-1081.

93. Molly, V., Laveren, E., \& Deloof, M. (2010). Family business succession and its impact on financial structure and performance. Family Business Review, 23, 131-147. 
94. Niehm, L.S., Swinney, J., \& Miller, N.J. (2008). Community social responsibility and its consequences for family business performance. Journal of Small Business Management, 46, 331-350.

95. O’Boyle, E.H., Rutherford, M.W., \& Pollack, J.M. (2010). Examining the relation between ethical focus and financial performance in family firms: An exploratory study. Family Business Review, 23, 310-309.

96. O'Brien, K.M. (2003). Measuring career self-efficacy: Promoting confidence and happiness at work. In S. J. Lopez \& C. R. Snyder (Eds.), Positive psychological assessment, (pp. 109-126). Washington, DC: American Psychological Association.

97. Odgers Berndtson (2013). Family Owned Business. Retrieved March 17, 2013 from http://www.odgersberndtson.co.za/za/industries-functions/specialty-practices /family-owned-business/

98. Okoroafo, S. C., \& Koh, A. (2009). The impact of marketing activities of family owned businesses on consumer purchase intentions. International Journal of Business and Management, 4(10), 3-13.

99. Onyishi, I.E., \& Ogbodo, E. (2011). The contributions of self-efficacy and perceived organisational support when taking charge at work. SA Journal of IndustrialPsychology, 38(1). doi:org./10.4102/sajip.v38i1.979.

100. Oweneel, E., Le Blanc, P.M., \& Schaufeli, W.B. (2012). Gain cycles of positive emotions, resources, and engagement at work. Career Development International, 17(6), 537-556.

101. Parada, M.J., Nordqvist, M., \& Gimeno, A. (2010). Institutionalizing the family business: The role of professional associations in fostering a change of values. Family Business Review, 23, 355-372.

102. Pearson, Q.W., Carr, J.C., \& Shaw, J.C. (2008). Toward a theory of familiness: A social capital perspective. Entrepreneurship Theory and Practice, 32, 949-969.

103. Peterson, C., Luthans, F., Avolio, B.J., Walumbwa, F.O., \& Zhang, Z. (2012). Psychological capital and employee performance: A latent growth modelling approach. Personnel Psychology, 64, 427-450.

104. Peterson, C., \& Steen, T.A. (2005). Optimistic explanatory style. In C. R. Snyder \& S. J. Lopez (Eds.), Handbook of positive psychology, (pp. 244-256). Cape Town: Oxford University Press.

105. Pick n Pay. (2002). Pick n Pay Annual Report 2002. Johannesburg: Pick n Pay.

106. Poutziouris, P.Z., Steier, L., \& Smyrnios, K.X. (2004). Guest editorial. A commentary on family business entrepreneurial developments. International Journal of Entrepreneurial Behaviour \& Research, 10, 7-11.

107. Poza, E.J. (2007). Family business ( $2^{\text {nd }}$ ed.). London: Thomson.

108. Prichard, D. (2004). Hearing grasshoppers jump: the story of Raymond Ackerman as told to Denise Prichard. Cape Town: David Philip.

109. Prichard, D. (2005). The four legs of the table. Raymond Ackerman's simple, straight-forward formula for success as told to Denise Prichard. Cape Town: David Philip.

110. Pukthuanthong, K., Walker, T.J., \& Theingtham, D.N. (2013). Does family ownership create or destroy value? Evidence from Canada. International Journal of Management, 9(1), 13-48.

111. Reivich, K., \& Gillham, J. (2003). Learned optimism: the measurement of explanatory style. In S.J. Lopez \& C.R. Snyder (Eds.), Positive psychological assessment, (pp. 57-74). Washington, DC: American Psychological Association.

112. Reynolds, T. (2012). 10 Family Business Lessons. Home Business Magazine: The Home-Based Entrepreneur's Magazine, 19(2), 53.

113. Robinson, S. \& Stubberud, H.A. (2011). Social Networks and entrepreneurial growth. International Journal of Management \& Information systems, 15(4), 65-70.

114. Royer, S., Simons, R., Boyd, B., \& Rafferty, A. (2008). Promoting family: A contingency model of family business succession. Family Business Review, 21, 15-30.

115. Salvato, C., Chirico, F., \& Sharma, P. (2010). A farewell to the business: Championing exit and continuity in entrepreneurial family firms. Entrepreneurship and Regional Development, 22(3/4), 321-348.

116. Sawyers, A. (2010). A century of hanging in there. Automotive News. 85(64), 4,30.

117. Schein, E. (1983). The role of the founder in creating organisational culture. Organisational Dynamics, 12 , 13-28.

118. Seligman, M.E.P. (1999). The president's address. American Psychologist, 54, 559-562.

119. Seligman, M.E.P. (2005). Positive psychology, positive prevention, and positive therapy. In C. R. Snyder \& S. J. Lopez (Eds.), Handbook of positive psychology, (pp. 1-12). Cape Town: Oxford University Press.

120. Snyder, C.R. (2000). Handbook of hope: Theory, measures, and applications. San Diego, CA: Academic Press. 
121. Snyder, C.R., Rand, K.L., \& Sigmon, D.R. (2005). Hope theory. A member of the positive psychology family. In C. R. Snyder \& S. J. Lopez (Eds.), Handbook of positive psychology, (pp. 257-298). Cape Town: Oxford University Press.

122. Sorenson, R.L., Goodpaster, K.E., Hedberg, P.R., \& Yu, A. (2009). The family point of view, family social capital, and firm performance: An exploratory test. Family Business Review, 22, 239-253.

123. Stajkovic, A., \& Luthans, F. (1998). Social cognitive theory and self efficacy: Going beyond traditional motivational and behavioral approaches. Organisational Dynamics, 26, 62-74.

124. Stavrou, E., Kassinis, G., \& Filotheou, A. (2007). Downsizing and stakeholder orientation among the Fortune 500: Does family ownership matter? Journal of Business Ethics, 72, 149-162.

125. Steen, A., \& Welch, L. S. (2006). Dancing with giants: Acquisition and survival of the family firm. Family Business Review, 15, 289-300.

126. Steier, L. (2009). Where do new firms come from? Households, family capital, ethnicity, and the welfare mix. Family Business Review, 22, 273-278.

127. Stockmans, A., Lybaert, N., \& Voordeckers, W. (2010). Socioemotional wealth and earnings management in private family firms. Family Business Review, 23, 283-284.

128. Sundaramurthy, C. (2008). Sustaining trust within family businesses. Family Business Review, 21, 89-102.

129. Sweetman, D., Luthans, F., Avey, J.B. \& Luthans, B.C. (2012). Capital and creative performance. Canadian Journal of Administrative Sciences, 28, 4-13.

130. Swamy, V. (2011). Corporate governance and firm performance in unlisted family owned firms. International Journal of Business Insights \& Transformation. 4(2), 37-52.

131. Tokarczyk, J., Hansen, E., Green, M., \& Down, J. (2007). A resource-based view and market orientation theory examination of the role of "familiness" in family business success. Family Business Review, 20, 1731.

132. Tsai, W., Kuo, Y., \& Hung, J. (2009). Corporate diversification and CEO turnover in family business: selfentrenchment or risk reduction? Small Business Economics, 32(1), 57-76.

133. Tsao, C., Chen, S., Lin, C., \& Hyde, W. (2009). Founding-family ownership and firm performance. Family Business Review, 22, 319-332.

134. Vallejo, M.C. (2009a). The effects of commitment of non-family employees of family firms from the perspective of stewardship theory. Journal of Business Ethics, 87, 379-390.

135. Vallejo, M.C. (2009b). Analytical model of leadership in family firms under transformational theoretical approach: An exploratory study. Family Business Review, 22, 136-150.

136. Vallejo, M., \& Langa, D. (2010). Effects of family socialization in the organisational commitment of the family firms from the moral economy perspective. Journal of Business Ethics, 96(1), 49-62.

137. Van der Merwe, S.P, Venter, E., \& Farrington, S.M. (2012). An assessment of selected family business values in small and medium sized family business. South African Journal of Business Management, 43(4), 17-31.

138. Van Wyk, R. (2012). Constrictive vs Distinctive Familiness and the Culturing of Familiness Capital (FamCap). African Journal of Business Management, 6(36), 9892-9900.

139. Venter, E., Van Der Merwe, W., \& Farrington, S. (2012). Southern African Business Review, 16(2), 69-96.

140. Venter, W.P. (2007). The role of familiness in the success and failure of family-business groups. Unpublished DCom thesis, University of Johannesburg, Johannesburg.

141. Venter, W.P. (2008). Ubuntu and social capital factors in family businesses. Southern African Journal of Entrepreneurship and Small Business Management, 1, 66-93.

142. Walumbwa, F.W., Luthans, F., Avey, J.B., \& Oke, A. (2011). Authentically leading groups: The mediating role of collective psychological capital and trust. Journal of Organisational Behavior, 32(1), 4-24.

143. Ward, J.L. (2004). Perpetuating the family business: Fifty lessons learned from long-lasting, successful families in business. New York, NY: Palgrave MacMillan.

144. Zahra, S.A., Hayton, J.C., Neubaum, D.O., Dibrell,C., \& Craig, J. (2008). Culture of family commitment and strategic flexibility: The moderating effect of stewardship. Entrepreneurship Theory and Practice, 32, 1035-1054.

145. Zainol, F.A., Daud, W.N.W., \& Muhammad, H. (2012). Entrepreneurial orientation (EO) in Malay family firm: Evidence from F-Pec model. International Journal of Business and Social Science, 3(20), 143-151.

146. Zellweger, T., \& Nason, R. (2008). A stakeholder perspective to family firm performance. Family Business Review, 21, 203-216. 
147. Zellweger, T.M., Eddleston, K.A., \& Kellermanns, F.W. 2010. Exploring the concept of familiness: Introducing family firm identity. Journal of Family Business Strategy, 1(1), 54-63.

148. Zellweger, T.M., Kellermanns, F.W., Eddleston, K.A., \& Memili, E. 2012. Building a family firm image: How family firms capitalize on their family ties. Journal of Family Business Stragegy, 3, 239-250. 
NOTES 